College of William \& Mary Law School William \& Mary Law School Scholarship Repository

2012

\title{
Book Review of Reclaiming Fair Use: How to Put Balance Back in Copyright
}

Benjamin J. Keele

bkeele@iu.edu

\section{Repository Citation}

Keele, Benjamin J., "Book Review of Reclaiming Fair Use: How to Put Balance Back in Copyright" (2012). Library Staff Publications.

77.

https://scholarship.law.wm.edu/libpubs/77

Copyright c 2012 by the authors. This article is brought to you by the William \& Mary Law School Scholarship Repository. 
Aufderheide, Patricia, and Peter Jaszi. Reclaiming Fair Use: How to Put Balance Back in Copyright. Chicago: University of Chicago Press, 2011. 199p. \$50.

Reviewed by Benjamin J. Keele

I1 The affirmative defense of fair use is one of the most vexing aspects of copyright law. Though codified in a statutory section that is only 175 words long, ${ }^{1}$ the doctrine has generated numerous law review articles ${ }^{2}$ and a major treatise ${ }^{3}$ dedicated to analyzing its history and judicial application. When fair use so often baffles legal professionals, it seems unfair to expect lay citizens to rely on it as justification for the use of copyrighted works in their own creative endeavors. American University professors Patricia Aufderheide (School of Communication) and Peter Jaszi (Washington College of Law) offer codes of best practices as one solution to this problem. Developed by individual creative communities, these codes "represent ... the community's current consensus about acceptable practices for the fair use of copyrighted materials" 4 and function as tools that can help users gauge whether a particular use of copyrighted material qualifies as fair. Aufderheide and Jaszi's new book, Reclaiming Fair Use: How to Put Balance Back in Copyright, serves both as a manual for developing these codes of best practices and as a readable story that recounts the historical development of fair use.

I2 The first half of the book summarizes the origins and the history of fair use. In large part, this account is also the more general tale of U.S. copyright law. Over the course of the last two centuries, Congress has gradually but steadily expanded the scope of works protected by copyright and extended the term of copyright protection, all to safeguard the interests of businesses in politically influential

1. 17 U.S.C. $\$ 107$ (2006).

2. See, e.g., Neil Weinstock Netanel, Making Sense of Fair Use, 15 Lewis \& Clark L. Rev. 715 (2011); Gideon Parchomovsky \& Philip J. Weiser, Beyond Fair Use, 96 Cornell L. Rev. 91 (2010); Matthew Sag, The Prehistory of Fair Use, 76 Brook. L. Rev. 1371 (2011).

3. William F. Patri, Patry on Fair Use (2011).

4. The Code of Best Practices in Fair Use for Media Literacy Education, CTR. FOR SOc. MEDIA, http://www.centerforsocialmedia.org/fair-use/related-materials/codes/code-best-practices-fair-use -media-literacy-education (last visited Feb. 6, 2012). 
industries. This has produced a "Long and Strong Copyright" (part of the title of chapter 2) that stifles those creative efforts that rely on preexisting copyrighted works for raw materials.

I3 Conventionally, the authors' narrative would veer off here in one of two opposing directions, either denouncing copyright infringers as thieves who deprive authors and publishers of hard-earned income or demanding that copyright be reformed-or even abolished-to remove a major obstacle to freedom of speech and access to information. Fortunately, Aufderheide and Jaszi eschew these wellworn paths. They advocate, instead, for the widespread use of collaboratively developed codes of best practices that can provide content creators with practical guidance on fair use and establish industry norms that can be consulted by lawyers, judges, funding agencies, and insurance companies. Such codes can boost the confidence that content creators have in their own decisions about fair use, thus promoting the generation of new creative works, even in political environments hostile to the legislative reform of copyright law.

I4 A recent shift in the courts' application of the fair use doctrine has made development of these codes more useful. The copyright act establishes a four-factor test for analyzing questions of fair use. In the 1970s and 1980s, under the influence of the law-and-economics movement, judges generally treated one factor, a use's effect on the market for the copyrighted work, as the most critical. "Since fair use inevitably involves not paying a license fee" (p.82), this focus left fair use largely irrelevant as a copyright defense. In the 1990s, however, courts shifted their emphasis to focus on the overarching issue of transformativeness, whether a particular use "repurpose[s]" (p.80) a copyrighted work for a new context. In an influential law review article, Judge Pierre Leval argued that fair use should favor transformative uses, ${ }^{5}$ and the 1994 U.S. Supreme Court decision in Campbell v. Acuff-Rose Music, Inc. endorsed this approach. ${ }^{6}$ This emphasis on transformation was "the key to open the fair-use door" (p.93). Now, when considering a question of fair use, courts ask three questions: "Was the use of copyrighted material for a different purpose, rather than just reuse for the original purpose? Was the amount of material taken appropriate to the purpose of the use? Was it reasonable within the field or discipline it was made in?" (p.135). By specifying the uses that a creative community considers reasonable, codes of best practices can help to answer the final question.

I5 At the time of the book's publication, eight "communities of practice" (p.155) had adopted codes providing guidance on fair use, including documentary filmmakers, poets, and media literacy educators. (The Association of Research Libraries subsequently adopted a code. ${ }^{7}$ ) The second half of the text discusses the drafting and adoption of these codes and the role that the book's authors played in these developments. With funding provided by major foundations, Aufderheide and Jaszi organized meetings of various creative communities, beginning with the

5. Pierre N. Leval, Toward a Fair Use Standard, 103 Harv. L. Rev. 1105 (1990).

6. 510 U.S. 569 (1994).

7. Assoc. of Research Libraries et al., Code of Best Practices in Fair Use for Academic and RESEARCH LibRARIES (2012), available at http://www.arl.org/bm doc/code-of-best-practices-fair-use .pdf. 
documentary filmmakers. At each meeting, participants discussed the situations commonly giving rise to issues of fair use within their particular community. A legal advisory board then vetted general principles regarding the appropriate scope of fair use within these situations and presented a code compiling the principles for potential adoption by organizations representing the creative community. Several case studies demonstrate that the codes of best practices resulting from these processes help to clarify what constitutes fair use, giving creators and copyright owners a better idea of which uses are appropriate and which should be licensed.

I6 Reclaiming Fair Use is an informative and readable call for content creators to work collectively in establishing fair use norms and asserting their fair use rights. It would make an excellent acquisition for any academic or public library that serves patrons who rely on fair use. In addition to their substantive material, Aufderheide and Jaszi provide a number of useful appendixes, including "Template for a Code of Best Practices in Fair Use," "Documentary Filmmakers' Statement of Best Practices in Fair Use," and "Myths and Realities about Fair Use." Sprinkled throughout the book are a number of text boxes labeled "Fair Use: You Be the Judge" that present scenarios prompting readers to evaluate the real-world application of fair use principles, and the book's final appendix provides the "answers" to these scenarios. 